\title{
Late Miocene wood recovered in Bengal-Nicobar submarine fan sediments by IODP Expedition 362
}

\author{
Lisa McNeill ${ }^{1}$, Brandon Dugan ${ }^{2}$, Katerina Petronotis ${ }^{3}$, Kitty Milliken ${ }^{4}$, Jane Francis ${ }^{5}$, and the \\ Expedition 362 Scientists ${ }^{+}$ \\ ${ }^{1}$ Ocean and Earth Science, National Oceanography Centre Southampton, \\ University of Southampton, Southampton S014 3ZH, UK \\ ${ }^{2}$ Department of Geophysics, Colorado School of Mines, Golden, CO 80401, USA \\ ${ }^{3}$ International Ocean Discovery Program, Texas A\&M University, \\ 1000 Discovery Drive, College Station, TX 77845, USA \\ ${ }^{4}$ Bureau of Economic Geology, University of Texas at Austin, 1 University Station, \\ Box X, Austin, TX 78713, USA \\ ${ }^{5}$ British Antarctic Survey, Madingley Road, Cambridge, CB3 0ET, UK \\ $\boldsymbol{+}_{\mathrm{A}}$ full list of authors appears at the end of the paper. \\ Correspondence: Lisa McNeill (lcmn@noc.soton.ac.uk)
}

Received: 3 September 2019 - Revised: 8 January 2020 - Accepted: 10 January 2020 - Published: 27 May 2020

\begin{abstract}
Drilling and coring during IODP Expedition 362 in the eastern Indian Ocean encountered probably the largest wood fragment ever recovered in scientific ocean drilling. The wood is Late Miocene in age and buried beneath $\sim 800 \mathrm{~m}$ of siliciclastic mud and sand of the Bengal-Nicobar Fan. The wood is well preserved. Possible origins include the hinterland to the north, with sediment transported as part of the submarine fan sedimentary processes, or the Sunda subduction zone to the east, potentially as a megathrust tsunami deposit.
\end{abstract}

IODP Expedition 362 drilled offshore at two sites (U1480 and U1481) in August-October 2016 on the Indian oceanic plate subducting at the Sumatra seismogenic zone (Fig. 1). The primary objective of the expedition was to characterize the input sediments that control the properties of the plate boundary fault zone responsible for the December 2004 magnitude 9.1 Sumatra-Andaman earthquake and resulting tsunami. The drill sites are situated on the Nicobar Fan part of the wider Bengal-Nicobar fan system composed of deep-water siliciclastic sediments derived from the uplifting Himalaya-Tibetan Plateau collisional system (McNeill et al., 2017a). At $3^{\circ} \mathrm{N}$, the latitude of sites U1480 and U1481, $1.5 \mathrm{~km}$ of sediment overlies the oceanic basement with water depths of $4.5 \mathrm{~km}$. In situ temperature measurements document a local geothermal gradient of $44.4^{\circ} \mathrm{C} \mathrm{km}^{-1}$ with a seafloor temperature of approximately $1.5^{\circ} \mathrm{C}$ (McNeill et al., 2017b).

During coring at Site U1480, two adjacent cores of interbedded sediment gravity flow and hemipelagic siliciclas- tic sediment containing large pieces of fossilized wood were recovered at $\sim 840-860 \mathrm{~m}$ below the seafloor. The sediments at this depth are Late Miocene in age $(\sim 9 \mathrm{Ma})$, based on biostratigraphic analysis (Backman et al., 2019). The largest wood fragment (in Core 362-U1480G-11R) is $14 \mathrm{~cm}$ in length along the core axis (Fig. 2). The second fragment is $6 \mathrm{~cm}$ in length within the next underlying core (U1480G12R). Both fragments have a black, lignitic appearance. Binocular microscope and SEM images of the large fragment from Core 11R (Fig. 3) reveal cellular and tubular structures that are slightly compressed in the plane of bedding by sediment compaction (Fig. 3c). This preliminary examination indicates that these are examples of angiosperm wood, based on pitted ray cells and fibers as well as the stacked layers of horizontal ray cells. Although the definitive vessels of angiosperm wood are not observed, these other characteristics support an angiosperm interpretation; moreover, we do not find any convincing evidence for the wood being conifer. The wood appears to be mummified rather than charcoalified 


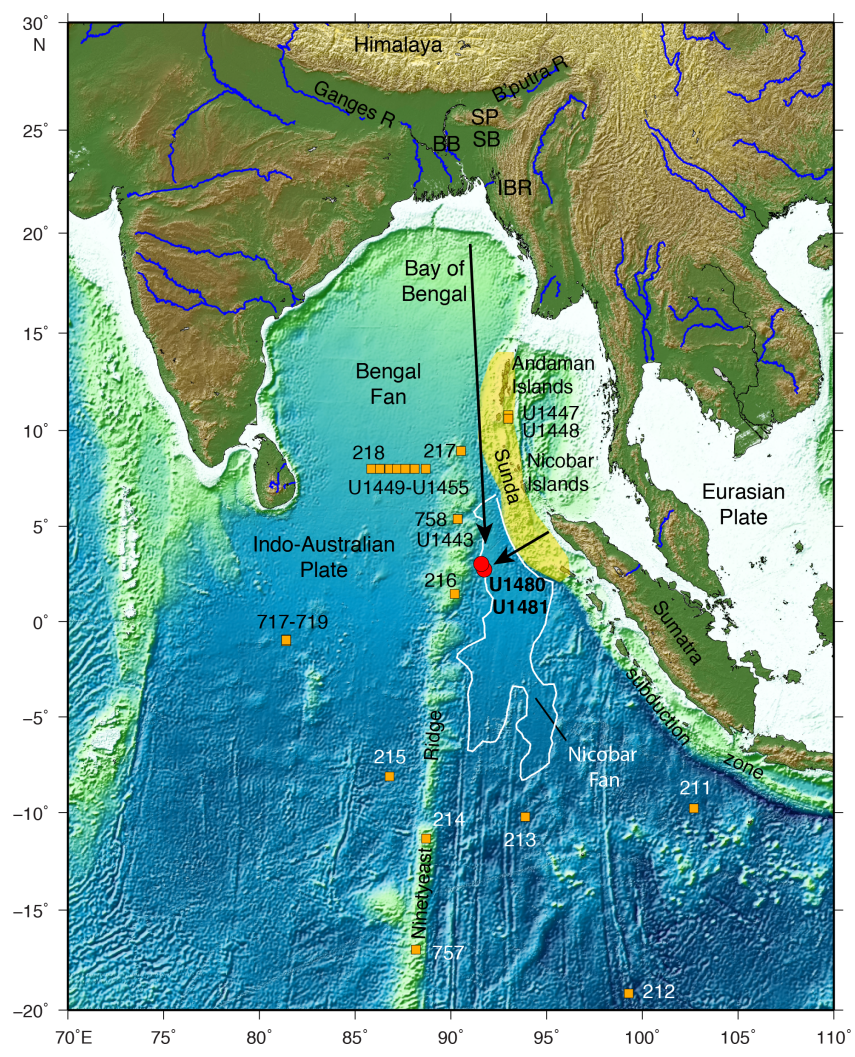

Figure 1. Eastern Indian Ocean map showing the IODP Expedition 362 drill sites (red dots) and the extent of the Nicobar Fan (white line). The yellow shaded area indicates the rupture area of the 2004 Sumatra-Andaman subduction earthquake. The wood could have originated from the north as part of the Bengal-Nicobar Fan transport or from the islands of the Sunda subduction zone to the northeast and east; this includes a possible tsunami transport origin triggered by a northern Sunda subduction zone earthquake, similar to the 2004 Sumatra-Andaman event (black arrows indicate possible pathways). Map uses GEBCO bathymetric data from the GEBCO_08 Grid data set obtained from the National Centers for Environmental Information (NCEI; previously NGDC). After McNeill et al. (2017a).

or coalified (Mustoe, 2018). We rule out charcoal because this would display crushing rather than compressional bending and plastic deformation in compaction, whereas coalified wood would require greater burial and thermal maturity (Mustoe, 2018). Mummification of the wood indicates that it was buried in a manner that protected it from oxidation and microbial degradation (Mustoe, 2018).

This find is extremely unusual, in terms of the size of the wood pieces, the age of the sediments within which they were deposited and preserved, and the depth of burial. Based on a search through previous DSDP, ODP, and IODP reports, the fragment from Core 362-U1480G-11R is believed to be the largest wood fragment cored in scientific ocean drilling history. Investigations are ongoing to try to identify the wood/tree type as well as its taxonomy and geographic

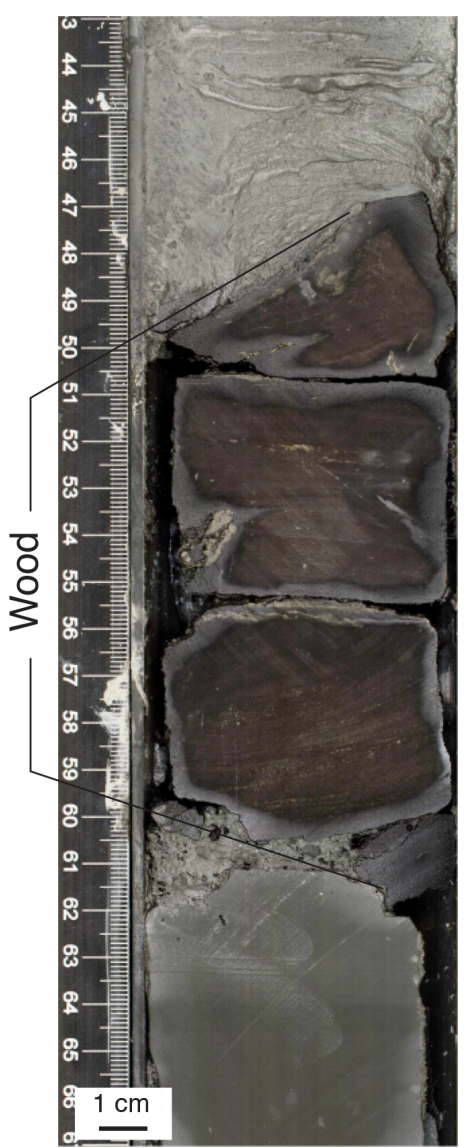

Figure 2. Section of Core 362-U1480G-11R, including the largest of the wood fragments. The image is lightened to highlight these fragments.

origin. The preservation state of these wood fragments may also provide qualitative information on seafloor conditions (e.g., oxygen and burial rate) that augment expedition sedimentary analyses. It is likely that the along-core length represents the width of the tree trunk and that the wood sample's long axis is laying horizontal, meaning that it is perpendicular to the core axis as a consequence of deposition on the seafloor. Therefore, we infer that the coring process sampled what would be a much larger section of woody material. Inspection of the wood fragment surfaces revealed no borings or epibionts.

Possible origins and transport processes of this wood material include (1) large-scale flooding and long-distance transport of material from the north within the BengalNicobar submarine fan system, (2) more regional transport from the islands of the Sunda subduction zone to the northeast and east (Sumatra, the Nicobar islands, and the Andaman islands), or (3) subduction zone tsunami debris similar to that created by the 2004 Sumatra-Andaman earthquake and tsunami that removed and washed away thousands of trees, whose settling locations are not known. Figure 1 shows 

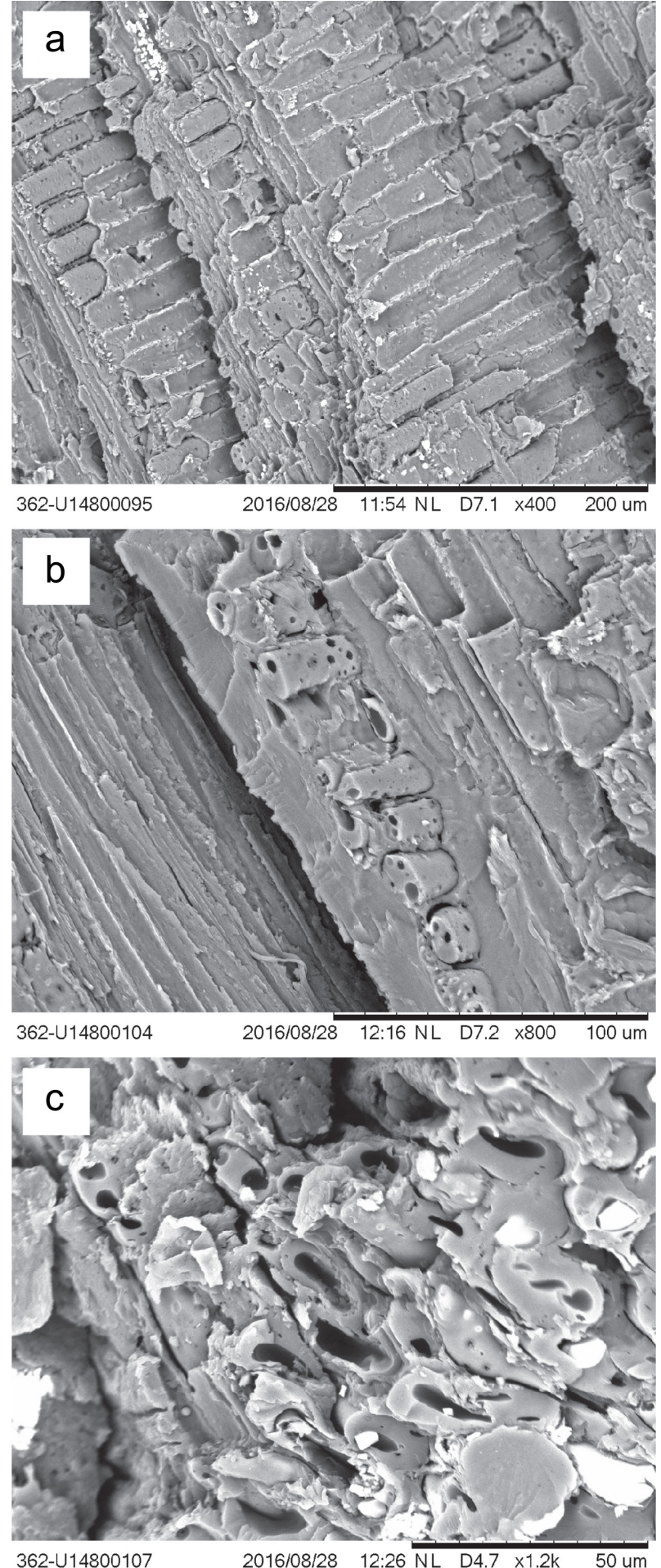

Figure 3. Shipboard SEM images of angiosperm wood fragments from IODP Site U1480 cores. (a) Radial view of ray cells showing rays cells (horizontal orientation in the original tree) with tiny pits on ray cell walls, and several ray cell lumen with infills. (b) Oblique view showing the tangential cross section of a ray composed of numerous cells (some with infilling). Vertical fibers are visible on the left. (c) Oblique transverse view showing the transverse section of fiber walls, which have been slightly compressed. these geographic regions relative to the drill sites and potential transport pathways.

Data availability. All IODP core and logging data related to the IODP Expedition 362 are open and available. These can be accessed at the following sites: http://web.iodp.tamu.edu/OVERVIEW/ (last access: 6 February 2020; McNeill et al., 2017b), and http://mlp. ldeo.columbia.edu/logdb/ (last access: 6 February 2020; McNeill et al., 2017b).

Team list. Jan Backman (Stockholm University, Sweden), Kevin T. Pickering (University College London, UK), Hugo F. A. Pouderoux (University de Rennes, France), Timothy J. Henstock (University of Southampton, UK), Farid Chemale, Jr. (Universidade do Vale do Rio dos Sinos, Brazil), Steffen Kutterolf (GEOMAR, Germany), Hideki Mukoyoshi (Shimane University, Japan), Wenhuang Chen (Chinese Academy of Sciences, China), Sarah Kachovich (University of Queensland, Australia), Freya L. Mitchison (Cardiff University, UK), Sylvain Bourlange (Université de Lorraine, France), Tobias A. Colson (University of Western Australia, Australia), Marina C. G. Frederik (Agency for the Assessment and Application of Technology (BPPT), Indonesia), Gilles Guèrin (LamontDoherty Earth Observatory at Columbia University, USA), Mari Hamahashi (Geological Survey of Japan (AIST), Japan), Brian M. House (University of California, San Diego, USA), Andre Hüpers (University of Bremen, Germany), Tamara N. Jeppson (University of Wisconsin-Madison, USA), Abby R. Kenigsberg (Pennsylvania State University, USA), Mebae Kuranaga (Yamaguchi University, Japan), Nisha Nair (National Centre for Antarctic and Ocean Research, India), Satoko Owari (Chiba University, Japan), Yehua Shan (Chinese Academy of Sciences, China), Insun Song (Korea Institute of Geoscience \& Mineral (KIGAM), Korea), Marta E. Torres (Oregon State University, USA), Paola Vannucchi (Royal Holloway University of London, UK), Peter J. Vrolijk (New Mexico Tech, USA), Tao Yang (China Earthquake Administration, China), and Xixi Zhao (University of California, Santa Cruz, USA).

Author contributions. All authors contributed to writing the paper. LM, BD, KP, KM, and the Expedition 362 scientists all participated in Expedition 362 and the collecting of cores and logs as well as their preliminary analysis. KM generated and performed the initial analysis of the thin sections and the SEM images. JF was responsible for the technical wood analysis.

Competing interests. The authors declare that they have no conflict of interest.

Acknowledgements. This research used samples provided by the International Ocean Discovery Program (IODP). The JOIDES Resolution crew and the IODP technical team are thanked for their contributions during Expedition 362. We thank the reviewers, Vanessa Bowman and George Mustoe, for constructive suggestions 
that improved the paper, in particular the technical descriptions of the wood.

Financial support. This research has been supported by the Natural Environment Research Council (support to Lisa McNeill, grant no. NE/P01297/1), the U.S. Science Support Program (a Post Expedition Activity award to Brandon Dugan), and by the IODP JRSO (support to Katerina Petronotis, NSF grant no. OCE-1326927).

Review statement. This paper was edited by Ulrich Harms and reviewed by Vanessa Bowman and George Mustoe.

\section{References}

Backman, J., Chen, W., Kachovich, S., Mitchison, F., Petronotis, K., Yang, T., and Zhao, X.: Data report: revised age models for IODP Sites U1480 and U1481, Expedition 362, in: Sumatra Subduction Zone, edited by: McNeill, L. C., Dugan, B., Petronotis, K. E., and the Expedition 362 Scientists, Proceedings of the International Ocean Discovery Program, 362, College Station, TX, USA, https://doi.org/10.14379/iodp.proc.362.202.2019, 2019.
McNeill, L. C., Dugan, B., Backman, J., Pickering, K. T., Pouderoux, H. F. A., Henstock, T. J., Petronotis, K. E., Carter, A., Chemale Jr., F., Milliken, K. L., Kutterolf, S., Mukoyoshi, H., Chen, W., Kachovich, S., Mitchison, F. L., Bourlange, S., Colson, T. A., Frederik, M. C. G., Guèrin, G., Hamahashi, M., House, B. M., Hüpers, A., Jeppson, T. N., Kenigsberg, A. R., Kuranaga, M., Nair, N., Owari, S., Shan, Y., Song, I., Torres, M. E., Vannucchi, P., Vrolijk, P. J., Yang, T., Zhao, X., and Thomas, E.: Understanding Himalayan Erosion and the Significance of the Nicobar Fan, Earth Planet. Sc. Lett., 475, 134-142, https://doi.org/10.1016/j.epsl.2017.07.019, 2017a,

McNeill, L. C., Dugan, B., Petronotis, K., and Expedition 362 Scientists: Sumatra Subduction Zone, Proceedings of the International Ocean Discovery Program, 362, College Station, TX, USA, https://doi.org/10.14379/iodp.proc.362.2017, 2017b.

Mustoe, G. E.: Non-mineralized fossilized wood, Geosciences, 8, 223, https://doi.org/10.3390/geosciences8060223, 2018. 